2004

\title{
Thomas Jefferson: The Revolution of Ideas
}

Richard B. Bernstein

New York Law School, richard.bernstein@nyls.edu

Follow this and additional works at: https://digitalcommons.nyls.edu/fac_books

\section{Recommended Citation}

Bernstein, Richard B., "Thomas Jefferson: The Revolution of Ideas" (2004). Books. 57.

https://digitalcommons.nyls.edu/fac_books/57

This Book is brought to you for free and open access by the Faculty Scholarship at DigitalCommons@NYLS. It has been accepted for inclusion in Books by an authorized administrator of DigitalCommons@NYLS. 


\title{
Thomas Jefferson \\ The Revolution of Ideas
}

\author{
R. B. Bernstein
}

OXFORD

UNIVERSITY PRESS 
To the memory of my father, Fred Bernstein, who will always live in my heart, and to my b'sheret, Danielle J. Lewis, whose faith in me never wavers and who taught me to believe in second chances.

\section{OXFORD}

\section{UNIVERSITY PRESS}

Oxford New York

Auckland Bangkok Buenos Aires Cape Town Chenna

Dar es Salaam Delhi Hong Kong Istanbul Karachi Kolkata Kuala Lumpur Madrid Melbourne Mexico City Mumbai

Nairobi São Paulo Shanghai Taipei Tokyo Toronto

Copyright (C) 2004 by R. B. Bernstein

Published by Oxford University Press, Inc.

198 Madison Avenue, New York, New York 10016

www.oup.com

Oxford is a registered trademark of Oxford University Pres

All rights reserved. No part of this publication may be reproduced, stored in a retrieval system, or transmitted, in any form or by any means, electronic,

mechanical, photocopying, recording, or otherwise, without the prior permission of Oxford University Press.

Design: Greg Wozney

Layout: Alexis Siroc

Library of Congress Cataloging-in-Publication Data

Bernstein, R. B., 1956-

Thomas Jefferson: the revolution of ideas / R. B. Bernstein.

p. cm. - (Oxford portraits)

Includes bibliographical references and index.

ISBN 0-19-514368-X (alk. paper)

1. Jefferson, Thomas, 1743-1826-Juvenile literature. 2. Presidents-

United States-Biography-Juvenile literature. 3. Jefferson, Thomas, 1743-1826-

Political and social views-Juvenile literature. 4. United States-Politics and government-1775-1783-Juvenile literature. 5. United States-Politics and government-1783-1865- Juvenile literature. I. Title. II. Series.

E332.79.B47 2003

$973.4^{\prime}, 6^{\prime} 092$ -

2003017866

987654321

Printed in the United States of America on acid-free paper

On the cover: Thomas Jefferson by Rembrandt Peale, 1805

Frontispiece: Bust of Thomas Jefferson by Jean-Antoine Houdon, 1789

\section{CONTENTS}

INTRODUCTION

1 A Young Gentleman of Vir GinIa (1743-1774)

"It would be to my advantage to go to the college" 18

2 “We HOLD THESE TRUTHS. .." (1763-1776)

"All men are created equal" 48

3 The HARD WORK OF ReVOlution (1776-1784)

"Almighty God hath created the mind free" 59

4 "BEHOLD ME AT LENGTH ON THE VAUNTED SCENE

OF EUROPE!” (1784-1789)

5 “THE PARTIES STYLED REPUBLICAN AND FEDERAL” (1789-1793)

6 Touching EarTh (1794-1797)

7 “THE REIGN OF WITCHES” (1797-1801)

"The aspect of our politics has wonderfully changed" 148

8 "We ARE ALl REPUBLICANS, We ARE ALL FEDERAListS" (1801-1805)

"Every difference of opinion is not a difference of principle" 166

"A Wall of Separation" 169

9 “A SPLENDID MISERY” (1805-1809)

10 ENTHUSIASM AND ANGUish (1809-1826)

"All eyes are opened, or opening, to the rights of man" 225

EPILOGUE:"TAKE CARE OF ME WHEN DEAD...."

CHRONOLOGY

FURTHER READING AND WEBSITES

HisTORIC SITES

INDEX 
Politicians and commentators tell us that we live in an era of unprecedented crisis. And yet Jefferson and his contemporaries lived their entire adult lives in an atmosphere of constant crisis. From 1765 to 1775 , they had to weather the dispute with Great Britain over the American colonists' rights and responsibilities within the British Empire. From 1775 through 1783, they had to declare and win American independence in a grueling war against one of the world's greatest military and naval powers. Beginning in 1776, they launched a series of unprecedented struggles to invent new forms of government to preserve the liberty they would win in that Revolution. Even after they adopted the Constitution in 1788, their sense of crisis was not at an end. Now they faced yet another series of struggles, spanning the rest of their lives, to make their new systems and institutions of government work, to conduct politics within a new and untried constitutional framework, to test whether political conflict and factional strife could be contained within the matrix of the Constitution. Even in retirement, Jefferson, Madison, and their colleagues were besieged by questions, pleas, and demands for advice and guidance.

Jefferson and his contemporaries always were aware how fragile these experiments in government were, and that awareness fed their sense of crisis. They were committed to preserving the American Republic, and they were willing to pay a high price for that commitment. Their devotion to these ideals ought to reassure us - and to challenge us. Jefferson and the other members of the Revolutionary generation had to learn on the run, and their most remarkable exercises of creative adaptation should challenge us to do likewise.

$A$ note on quotations: Jefferson and his contemporaries wrote before the standardization of spelling, capitalization, and punctuation. Thus, all quotations appear as they do in their original sources.

\section{A YOUNG GENTLEMAN OF VIRGINIA (1743-I774)}

Thomas Jefferson told his children and grandchildren that his earliest memory was of a trusted slave carrying him, at the age of two, on a pillow when his family moved from his birthplace, the Shadwell plantation, to the Tuckahoe plantation, along the James River above Richmond, Virginia. Eighty-one years later, in 1826, as Jefferson lay on his deathbed, another trusted slave obeyed his dying request to have his pillows adjusted so that he could lie more comfortably. From cradle to grave, Jefferson was surrounded and supported by the institution of slavery, a core element of the life of Virginia's gentlemen farmers. No matter how modern, even forward-looking, he seems to us, he was a product of his time and place.

Jefferson, a member of one of Virginia's most prominent families, was born and raised on the western edge of Great Britain's American empire. His early makeup thus blended aristocrat and frontiersman. He was born in April 1743 at Shadwell, in Goochland (later Albemarle) County. He recorded his birth date as April 2,1743, under the "Old Style" (the "O.S." referred to in the inscription on his tombstone) calendar used in England until 1758. When in that year 
the British adopted the more reliable Gregorian calendar, all dates shifted forward 11 days; thus, we observe Jefferson's birthday on April 13.

Jefferson's mother, Jane Randolph Jefferson, born in 1720 , was one of the wealthy, proud Randolphs, the most numerous family in Virginia's planter elite. The Randolphs claimed to be descended from the royal houses of England and Scotland-claims that Jefferson dismissed as arrogant and pointless. We know almost nothing about Jane Randolph Jefferson. No letters between her and her son survive, and the few surviving references to her in his papers are cold and matter-of-fact.

By contrast, Jefferson was proud of his father. Born in 1708, a descendant of immigrants from Wales, Peter Jefferson won fame and respect for his industry, strength, endurance, and skill as a surveyor and mapmaker. In 1751, with Joshua Fry, he surveyed Virginia and prepared the first accurate map of the province. Thomas Jefferson proudly reprinted his father's map in his only book, Notes on the State of Virginia (1787). As an old man, he told his grandchildren stories of his father's heroic feats. For example, according to tradition, Peter once ordered his slaves to pull down a building on his plantation. When they confessed that they could not do it, he seized the rope and, with one mighty pull, brought it down himself.

Unlike Alexander Hamilton, whose brilliance as a child attracted the attention of his admiring elders, the young Thomas Jefferson is a shadowy figure. All we have are stories of his upbringing that he told his children and grandchildren. He had two older sisters, one younger brother, and two younger sisters. One older sister, Elizabeth, suffered from some form of mental retardation. In early 1774 , at the age of 28 , she wandered from the family house during a thunderstorm and was found dead after the storm. The few letters of Jefferson's younger brother, Randolph, suggest that he was, at most, of average intelligence. One thing we know about the young Jefferson is that, by the age of nine, he already enjoyed music and could play the violin; he often accompanied his adored older sister Jane when she sang.

Self-made and self-taught, Peter Jefferson valued education, and he inspired a similar love of learning in his oldest son. Because colonial Virginia had no public schools, gentleman farmers hired private tutors to teach their children. Thus, the very young Thomas Jefferson was tutored at home. When Thomas was nine, Peter enrolled him in a local private school run by the Reverend William Douglas. Douglas taught Latin and Greek, the basis of a gentleman's education. Although Thomas took to the classical languages easily, he did not like Douglas and thought little of his abilities.

In 1757, when Thomas was 14, Peter Jefferson died at the age of 49. His will named two friends to oversee the family's finances and serve as guardians for the children. They found Thomas a new tutor, the Reverend James Maury. In his autobiography, Jefferson called Maury a "correct classical scholar," which, for him, was a great compliment. For two years, Maury guided Thomas's study of Latin, Greek, classical literature, mathematics, and other subjects. The boy valued Maury's mastery of Greek and Latin, but disliked his tutor's narrow views. Maury denounced anyone who did not belong to the Church of England, and he eventually took Britain's side in its disputes with the American colonies.

In 1760 , when he was 17 , Jefferson decided that he had learned all that he could from Maury. He therefore wrote a letter to John Harvie, one of his guardians, asking permission to attend the College of William and Mary at Williamsburg, the capital of Virginia. Harvie found this idea sensible, and soon Jefferson traveled, with his slave Jupiter, to Williamsburg, the first town of any size that he had seen. In the 1770 s, Williamsburg had about 2,000 inhabitants, nearly half of them African slaves. The town was a collection of modest, well-tended brick and wooden buildings. At its center were the capitol, the governor's palace, and the College of William and Mary. 


\section{\begin{tabular}{l} 
"IT \\
TO \\
\hline Writin \\
his gu \\
Mary, \\
Jefferso \\
ence th \\
only coll \\
letter fio \\
\end{tabular}}

"IT WOULD BE TO MY ADVANTAGE TO GO TO THE COLLEGE"

Writing on January 14, 1760, the 16-year-old Thomas Jefferson sought to persuade his guardian, John Harvie, to allow him to attend the College of William and Mary, in Williamsburg, Virginia. Harvie granted permission, and the young Jefferson became an eager and brilliant student at William and Mary. His experience there, however, left him dissatisfied with the education offered by Virginia's only college and with the architecture of the college buildings. This is the earliest letter from his pen that survives. as I stay at the Mountains the Loss of one fourth of my Time is inevitable, by Company's coming here \& detaining me from School. And likewise my Absence will in great Measure put a Stop to so much Company, \& by that Means lessen the Expences of the Estate in HouseKeeping. And on the other Hand by going to the College I shall get a more universal Acquaintance, which may hereafter be serviceable to me, \& I suppose I can pursue my Studies in the Greek \& Latin as well there as here, \& likewise learn something of the Mathematics. I shall be glad of your opinion.
William and Mary was the second-oldest college in America (after Harvard). By modern standards, it was not much of a college. Most students paid little attention to academic requirements or to learning. Nearly all of the courses were lectures; professors seemed not to care whether their students showed up. Like their counterparts at the English universities of Oxford and Cambridge, students at William and Mary devoted their energy and enthusiasm to betting on horse races, playing dice and cards, and courting ladies. Though Jefferson sampled these distractions, he preferred to throw himself into study. His main diversion was his enthusiasm for his violin. Indeed, during the Christmas holidays just before he entered William and Mary, he met another young violinist, Patrick Henry; the two musicians entertained their fellow holiday revelers during the two-week vacation.

Jefferson attended William and Mary from 1760 until his graduation in 1762. His true education took place outside the classroom, thanks to Professor William Small. Small, who taught mathematics and "natural philosophy" (what we call science), was the college's best professor, and the only one who was not a minister of the Church of England. Barely 10 years older than Jefferson, Small befriended the gangly, redheaded student and introduced him to Francis Fauquier, Virginia's lieutenant governor, and George Wythe, a prominent lawyer.

Jefferson soon became a regular member of this cheerful, learned group, who treated him as a younger equal. Jefferson drank in all that he could learn from them, and Fauquier often assembled Jefferson and other musicians to join him in informal concerts of chamber music. The greatest legacy of Jefferson's college years was his friendship with Wythe. Born in 1725 , Wythe was one of the two leading attorneys in Virginia and was famous for his learning and culture. He often discussed law with Jefferson, who decided to study law with Wythe after his graduation from William and Mary.

In this period, there were no law schools. Instead, a wouldbe lawyer "read law" under the guidance of an established 


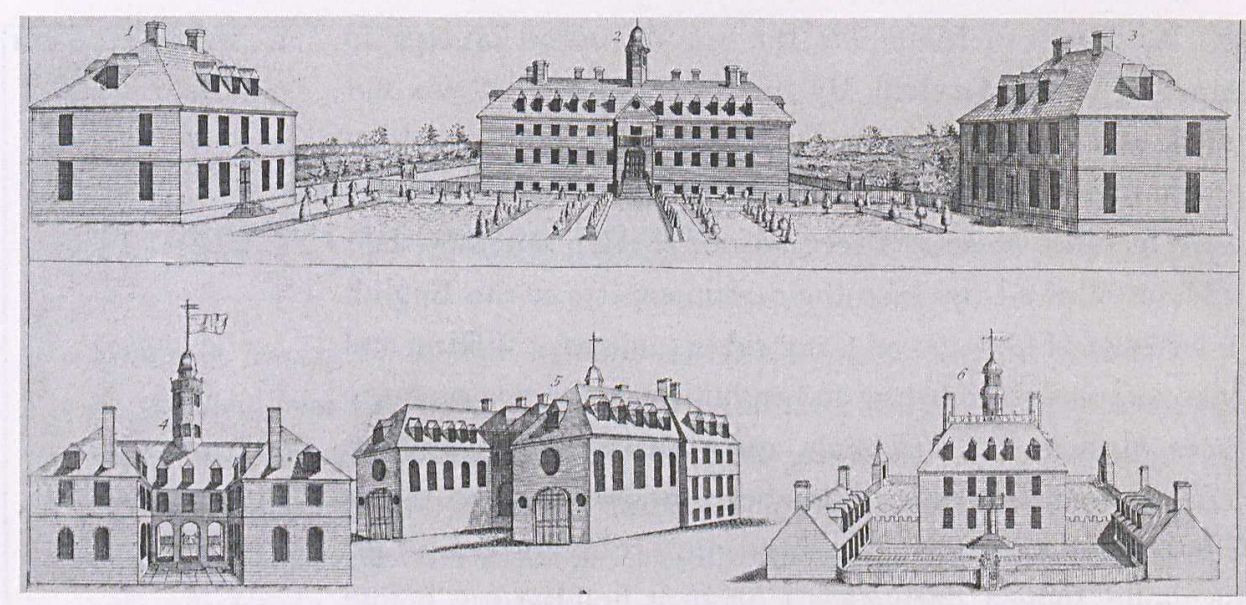

This is the only known 18th-century picture of the College of William and Mary, from which Thomas Jefferson was graduated in 1762

Jefferson's criticism of William and Mary spurred his later efforts to found the University of Virginia at Charlottesville. member of the bar. Reading law meant two things: studying (and puzzling over) legal treatises; and the drudgery of copying writs (the legal documents used to conduct lawsuits), wills, contracts, and letters. Copying was supposed to pound into the student's brain the form of legal documents and the feel of legal language.

The law books that most English and American lawyers studied were the works of the 17th-century jurist Sir Edward Coke. Coke's writings boiled down the wisdom of English law as established by decades of judicial decisions and elaborated by generations of lawyers - a system known as "common law." Coke wrote in the convoluted, thorny prose of the 17th century, and on Christmas Day of 1762 the young Jefferson complained bitterly in a letter to his friend John Page, "I do wish the Devil had old Coke, for I am sure I never was so tired of an old dull scoundrel in my life." It was a view he shared with nearly every law student of his time, but, unlike most of them, Jefferson learned his Coke thoroughly.

Wythe was not just a lawyer but a scholar, and he refused to let Jefferson's legal training rest on the threadbare formula of Coke and copying. Rather, he used a plan modeled on his own habits of thought and reading; he wanted his students to love the law as a body of learning, to be devoted to its study, and to adopt high standards of legal research and argument. Wythe had Jefferson read history, philosophy, and ethics to provide intellectual context for the dry materials of the law. When Jefferson later trained aspiring lawyers, he used the plan of legal education that Wythe had used with him.

Wythe instructed three generations of Virginia lawyers, but Jefferson was his favorite student, and Jefferson revered his mentor. Jefferson even modeled his small, neat handwriting and his rejection of capital letters to begin sentences on Wythe's. The two remained friends and political allies until Wythe's tragic murder by poisoning in 1806, apparently the deed of a grandson angered by Wythe's decision to cut him out of his will. On August 31, 1820, Jefferson sketched Wythe's life for the biographer John Sanderson, painting Wythe as more virtuous than the Roman senator Marcus Cato, a role model for 18th-century Americans steeped in Greek and Roman classics:

No man left behind him a character more venerated... His virtue was of the purest tint, and, devoted as he was to liberty, and the natural and equal rights of men, he might truly be called the Cato of his country, without the avarice of the Roman; for a more disinterested person never lived. Temperance and regularity in all his habits gave him general good health, and his unaffected modesty and suavity of manner endeared him to every one.... Such was George Wythe, the honor of his own, and model of future times.

In 1767 , after studying with Wythe for nearly five years (more than twice as long as the usual course of reading law), Jefferson became a member of the Virginia bar. He did not have to face the bar exam that modern lawyers must pass. Rather, Wythe swore to a committee of established lawyers that his student was honorable, able, and well trained. Then Jefferson answered the lawyers' questions on legal issues. Finally, he took the oath of membership and dined with his sponsor and examiners.

Jefferson lived up to Wythe's hopes for him. His learning, his literary and legal talent, and his membership in two of 
Virginia's great families vaulted him into the top rank of Virginia's lawyers. Like Wythe, he established a legal practice that focused on issues of real property and inheritance; in colonial Virginia such matters were of vital interest to the planters who gave lawyers most of their business. Also like Wythe, he was more attracted to the intellectual side of lawyering than to the work of the courtroom, but he tried his share of cases and won many of them.

In November 1774, Jefferson retired from practicing law. He and his colleagues had protested the low legal fees mandated by Virginia's laws, but he had another reason for giving up the practice of law: he did not need to support himself that way. He saw himself first as a gentleman planter. A farmer tilled the soil with his own hands, whereas a planter hired help (or bought slaves) to run his farm for him. A gentleman was a man who was independent - that is, his source of income did not depend on an employer. Gentlemen were not expected to worry about making ends meet; they were supposedly above such matters. Also, gentlemen were supposed to behave in ways that suited members

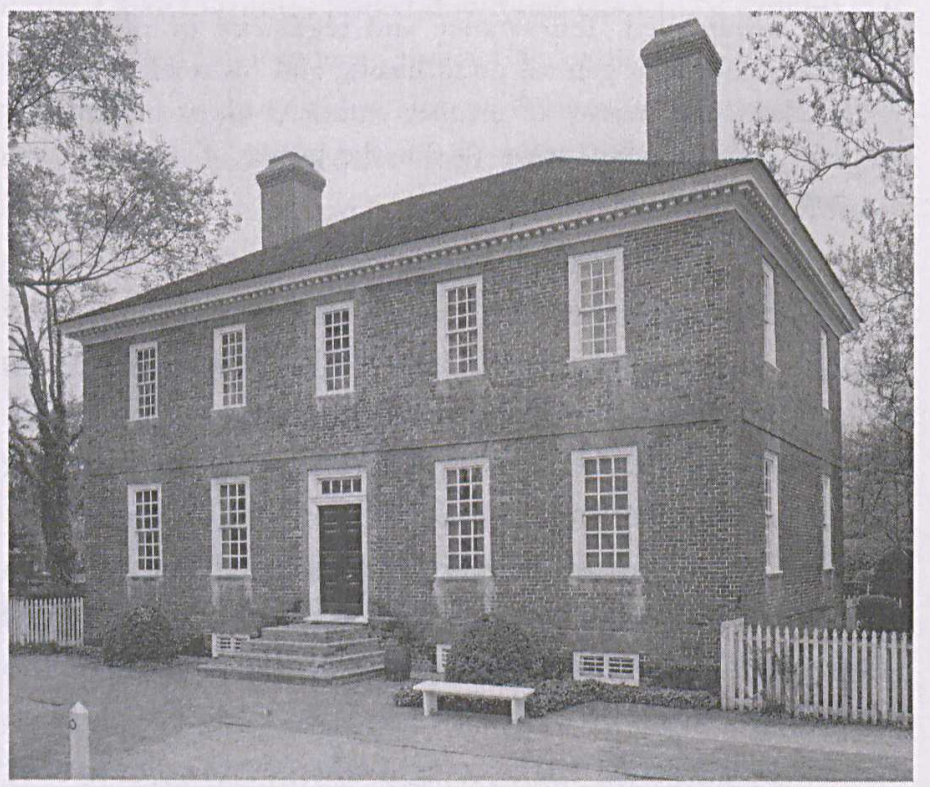

of the social and political elite. They were expected to govern themselves, to be careful about how they spoke and acted. In particular, they sought to safeguard their honor and reputation, for these made a gentleman's word worth taking, entitled him to the respect of his neighbors and his social inferiors, and made him trustworthy in business and worthy of political leadership.

By birth and training, Jefferson was a young gentleman of Virginia, a member in good standing of the province's governing class. Thus, it was no surprise when in 1768 his neighbors elected Jefferson to represent them in the House of Burgesses, the Virginia legislature's lower house. He did not have to campaign for office. Instead, his election was a matter of ceremony. Voters, guided by the community's leading gentlemen, agreed to elect the candidate pre-chosen by that group. A candidate would treat the voters to drinks, either by rolling large barrels of punch and hard cider onto his lawn or by throwing a party at a convenient tavern. When two leading men wanted the same office, they competed for their neighbors' votes by handing out food and drink. On election day, each voter would step up to the ballot box and announce his choice, receiving the candidate's thanks and enduring the jeers of those on the other side.

Jefferson seemed to be a typical member of the planter elite. However, his surviving papers show that he was different. He was more interested in the life of the mind, more intellectually venturesome, more inclined to question established customs. Like other educated gentlemen of his time, he kept a notebook into which he copied extracts from books that struck his fancy. The author to whom he devoted the most space in his notebook was the controversial skeptic Lord Bolingbroke, whose questioning of Christianity and opposition to political corruption struck chords with Jefferson.

In August 1771, Jefferson gave Robert Skipwith (one of his in-laws) a list of books that should be included in a gentleman's library-a list that offers clues as to his own 
reading. He recommended key authors of the Enlightenment, such as Locke, Hume, Bolingbroke, and Montesquieu, and advocated the habits of wide and deep reading that Wythe had taught him. He kept his daring speculations on religion to himself, however. Few of his contemporaries knew what was lurking in his mind and heart.

At this time, Jefferson prepared to set up an independent home for himself. As Peter Jefferson's oldest son, he had inherited most of his father's estate, including his birthplace, Shadwell, where he lived with his mother and sisters. Jefferson never explained his reasons for moving, but we know, for one thing, that he was doing what other planters did. Many planters built several houses, each the nerve center of its own plantation; if they had to sell a plantation, it would sell more easily with a ready-to-occupy house. Further, he may have wanted to try out his budding architectural ideas, inspired by studying the works of the 16th-century Italian architect Andrea Palladio.

Jefferson chose for his building site a low hill four miles from Shadwell; he leveled the hilltop and began to plan a house that he called Monticello, from the Italian word for "little hill." In February 1770, a fire at Shadwell, which destroyed his first library and his painstakingly amassed collection of legal notes and papers, spurred his plans. Monticello became one of the chief joys of his life, blending hobby and obsession.

Jefferson also may have begun Monticello as a home for a future wife. Young, wealthy, handsome, and of good family, he was a highly eligible bachelor. In Virginia, as in England, single gentlemen and ladies sought one another out in an elaborate, formal process of courtship. A key goal of this process was to improve their social and economic standing by uniting their fortunes and estates. Jefferson was aware of this principle, but he also held highly romantic views of women. As a college student, he courted the local beauty Rebecca Burwell, but she rejected him, later marrying his friend Jacquelin Ambler. He brooded over this rejection in letters to his friends that mingled heavy-handed humor with great helpings of self-pity, and he consoled himself with his violin. In the late 1760 s, after his admission to the bar, he befriended a neighboring planter, John Walker. Unfortunately, he also developed a strong passion for Walker's wife; he tried, as he later admitted, to seduce her, but she spurned his advances. (His clumsy gallantry came back to haunt him four decades later.)

Finally, he found someone who suited him and whom he suited-Martha Wayles Skelton, a recent widow and one of Virginia's wealthiest women. They married on January 1, 1772 , in a wedding hosted by her father, the planter, lawyer, and slave trader John Wayles. Thomas was 28 and Martha was 23 . Two weeks later, braving snowdrifts and treacherous roads, the newlyweds arrived at Monticello, which was just a building site with only one habitable room, what is now Monticello's South Pavilion.

No portrait of Martha Jefferson survives, but we know that she was short, slight, and famed for her beauty and talents. Like Jefferson, she loved music. As the story goes, when other suitors found her playing a duet on her harpsichord with Jefferson on his violin, they decided that he had won the day. She was an able household manager, she shared some of Jefferson's tastes in reading (they both loved Laurence Sterne's comic novel Tristram Shandy), and she did not favor his political career, preferring him to remain home.

By 1772, when Jefferson married, his way of life was under siege. Most Virginia planters raised tobacco, but the crop was hard to grow and leached nutrients out of the soil at an alarming rate. Battling the problem of exhausted farmland, planters rotated crops from plantation to plantation, letting the worn-out soil renew itself. Thus, prominent planters owned several plantations, having bought them, inherited them, or acquired them through marriage. The need for good land drove them to look westward, to expand their holdings or to speculate in buying and selling land. 
Virginia planters and farmers faced a more ominous burden-debt. Farming has always been a hard way to make a living. Virginia planters and farmers not only had to borrow money to buy land and seed to grow the crops on which they depended; they also had to hire overseers and buy slaves. Though they did not pay the slaves, they had to feed, house, and clothe them. Great planters found farming as hard and risky as small farmers. They kept watch over the weather, the soil's condition, and the prices their crops fetched at market. They dreaded downturns in prices, which would reduce the money they could use to pay their debts.

Obsessed with debt, Virginia planters and farmers kept careful account books, listing every debt they owed and every debt owed to them. Such "book debts" often took the place of cash. For example, a planter would give a note (a written promise to pay) in exchange for goods he wanted to buy. A note set forth the amount he owed, the rate of interest he would have to pay, the date when he assumed the debt, and the date when it would come due. The person receiving the note would record it in his account books so that he, or his heirs, would know what he was owed and be able to collect when the time was right. Sometimes one planter would take a debt owed to him by a second and sign it over as payment for a debt he owed to a third, or to a merchant. Such transactions became tangled over the years.

Complex networks of debt linked colonial planters to one another and to merchants in Williamsburg, Baltimore, Philadelphia, and London. Although planters kept track of debts owed to them and debts they owed, they still amassed debts. Being a planter meant keeping up appearances - in particular, giving the impression of carefree wealth. Thus, planters would give dinners for two or three dozen guests with many courses and fine wines; they would put up visitors for days or weeks at a time; and they would purchase from Europe the best clothing, furniture, hunting dogs, and firearms. For example, the newlywed Jefferson ordered his
London agent to buy the finest new pianoforte for Martha, and he regularly made other luxury purchases-fabrics, books, wines, sheet music and musical instruments, furniture, even carriages - all on credit, each bringing another debt.

Virginia's planters, entangled in debt, often likened themselves to flies caught in a spider's web, even though these webs were mostly of their own making. They thought that, because they were gentlemen, their mere word was guarantee enough that they would repay their debts. They resented merchants' and moneylenders' demands for payment, for those demands implied that they could not be trusted to repay.

Jefferson was a typical man of his time and social standing. Once he became an adult, he began the luxurious way of life that he followed until his death, piling up debts in the process. In 1773, John Wayles, his father-in-law, died, leaving vast landholdings to his daughter Martha, which, under Virginia law, actually went to Jefferson as her husband. Because Wayles owned many slaves, this inheritance made Jefferson one of the largest slaveholders in Virginia. (One of these slaves was Betty Hemings, with whom Wayles had had a sexual relationship that produced at least one daughter, Sally Hemings; Martha Wayles Jefferson and Sally Hemings were half-sisters.) However, Wayles had used many of his

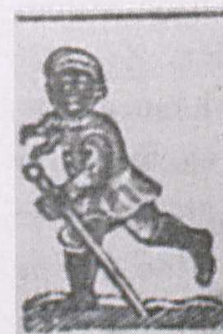

R UN away from the fubfcriber 1. in Albemarle, a Mulatto flave called Sandy, about 35 years of age, his ftature is rather low, inclining to corpulence, and his complexion light; he is a froemaker by trade, in which he nfes his left hand principally, can do coarfe carpenters left hand principally, can do corfe jockey $;$ he is work, and is fomething of a horfe jockey $;$ he is greatly addicted to drink, and when drunk is infomoch, and in his behaviour is artfol and knavifh. He took with moch, and in his behaviour is art with traces, of which it is exhim a white horle, much fearred wofe; he alfo carried his thoepected he will endeavour to difpole, he alfo camployment that makers tools, and will probably endeavour to get employment that way. Whoever conveys the faid flave to me, in Albemark, that have 40 s. reward, if taken up within the county, 41 . if elfe within the colony, and tol. if in any other colony, from
THOMAS JEFFERSON.
On September 14 , 1769, Thomas Jefferson placed this advertisement in the Virginia Gazette seeking aid in recovering a runaway slave named Sandy. As was usual in such ads, Jefferson gave a detailed word-portrait of Sandy's appearance, habits, abilities, and distinguishing traits. 
lands to guarantee his debts. When he borrowed money, he used land to secure the loan, so that the lender either would be repaid or could take the pledged land for himself.

Jefferson faced a problem, one that also faced his fellow heirs. Should they pay the estate's debts first, and take what was left? Or should they take the lands, and their accompanying burden of debt, in the hope that they could farm them or sell them and make enough money to pay those debts? In the end, they split the difference, selling some lands but keeping others.

The problem was that, by taking the lands with the debts, the heirs put their entire fortunes under the shadow of the debts that John Wayles owed at his death. These transactions transformed the nature of the debts. Before, they were attached to the land, like a mortgage. After, they became personal obligations of the person who took possession of the land, and all of that person's assets would be at risk when the time came to satisfy the debt.

As a lawyer, Jefferson should have known that he was putting his financial future at risk, but, as he so often did, he hoped that he would find a way to pay off these debts and trusted the future. Unfortunately, the future dashed his hopes. This was the first of a series of transactions by which he saddled himself with ever-growing debts that haunted him until his own death more than half a century later.

Even in normal times, the problem of debt loomed large for the Virginia elite, embittering their relations with British creditors. However, in the 1760 s and 1770 s, growing disputes between the colonies and Britain disrupted the network of debts linking Virginia to London. These developments set in motion political, legal, social, and economic forces that would lift Jefferson to great historical importance and, at the same time, mount new assaults on the social and economic leadership of Jefferson and those like him.

\section{"WE HOLD THESE, TRUTHS ... (I763-I776)}

In 1763, the 20-year-old Thomas Jefferson was a proud subject of King George III who never dreamed that, by the time he was 33, he would help to break up Britain's American empire. The American Revolution transformed Jefferson. Not only did it give him a focus and sense of mission-a chance to be not just a politician but a statesman-it also inspired his first creative political and intellectual labors, and gave him his greatest claims to fame.

When Jefferson was elected to the Virginia House of Burgesses in 1768 , he joined radical members such as Patrick Henry and George Washington against those backing the royal governor. Virginia's politics were like politics in the other colonies. Although each colony had unique issues, their politics all followed a general pattern, pitting officials sent from England to govern the colonies (and their local allies) against those colonists who sought to govern themselves.

Gentlemen planters made up Virginia's governing class. Understanding their political role as one of leadership by right of birth, they saw legislative seats as their personal property. Sometimes, someone not born into that class might win power. For example, Patrick Henry used his speech- 